\title{
Addressing Poor Performance in the Advanced Level Agriculture Syllabus (9159) in the Midlands Province, Zimbabwe
}

\author{
Constantino Pedzisai, Anceta Chiwara, Beauty Dondo, Maria Tsvere and \\ Simbarashe Munikwa \\ Chinhoyi University of Technology, Department of Curriculum and Instruction, Institute of Lifelong Learning, $P$ \\ Bag 7724, Chinhoyi, Zimbabwe
}

\begin{abstract}
The purpose of the study was to investigate factors contributing to poor performance in the Zimbabwe Advanced LevelAgriculture syllabus (9159) in two selected high schools in the Midlands province; Zimbabwe.This case study adopted the descriptive research design. A census sampling technique was used to select all the twenty five Advanced Level Agriculture students and their three teachers from the two selected schools. The study used questionnaires for students and interviews for Agriculture teachers to collect the required data. Quantitative data was analysed using statistical tables and graphs while qualitative data was analysed using common themes and patterns permeating the study. The research found out poor science background, poor subject combination at Advanced level, lack of science equipment, unavailability of textbooks for the syllabus and lack of funding for field trips and seminars as the major challenges schools faced when teaching the syllabus. The study recommends provision of adequate teaching/learning equipment, relevant textbooks, qualified teachers and ICTs to improve the performance in the subject.
\end{abstract}

Key terms: Student, Advanced level, Agriculture syllabus, High school, Teacher, Poor performance

\section{Introduction}

The Zimbabwe Advanced Level ('A' Level) Agriculture syllabus (9159) was designed for students who, after going through it, intend to follow more advanced courses in Agriculture at colleges and universities (ZIMSEC, 2008). The syllabus emphasizes the development of positive attitudes towards agriculture so that its graduates can see agriculture as a viable source of occupation that can lead to personal and community development. The sole aim of the Zimbabwe government in coming up with the syllabus was, thus, to produce an agricultural expert who meets the local and international standards in terms of competence. Agriculture is a very important subject due to its contribution to the country's economy, so students' performance in this subject is a matter of concern.

The syllabus in question places much emphasis on the understanding and application of scientific concepts and principles of agriculture and this focus has been adopted in recognition of the need for students to develop skills that will be relevant in the world of work (ZIMSEC, 2008). It therefore requires a student to have a strong Science and Mathematics background besides that of Agriculture. 'A' Level Agriculture is supposed to be offered to schools that have been assessed and approved by the Ministry of Primary and Secondary education as being soundly equipped to provide suitable courses of practical work both in the laboratory and in the field. Agriculture is a subject which is related to the environment of most schools and is part of the life experience of most students hence the teaching and learning of the subject should take full advantage of the resources of pupils' experience and environment around the schools (ZIMSEC, 2008). This however depends on the teacher's ability to use teaching methods that tap the pupils' experience.

The Midlands Province has 10 high schools which are offering Agriculture at 'A' Level. There is concern in under performance of students in A Level Agriculture in some of these schools yet ZIMSEC (2008: 3) says the subject "... is related to the environment of most schools and is part of the life experience of most students hence the teaching and learning of the subject should take full advantage of the resources of pupils' experience and environment around the schools." Furthermore, only small numbers are dealt with and the students would have passed Ordinary level ('O' Level). However instead of improving, the pass rate plummets or starts off badly.

Two schools were selected from Midlands, a Mission Boarding school and a Government Rural Day Secondary school. While the Mission Boarding school enrols students from different corners of the country, the Government Rural Day Secondary school enrols students mainly from its immediate catchment area. In the 2012 'A' Level Agriculture examination the Mission Boarding school's pass rate fell to 48\% from 53\% in 2011. 
The Government Rural Day Secondary school had its first 'A' Level Agriculture examination in November 2012 with only 6 candidates of whom one passed with an E, giving a pass rate of $16,7 \%$.

There is, therefore poor, performance in Agriculture at A level in some schools in the Midlands province especially in the two selected high schools. Academic performance, which is measured by the examination results, is one of the major goals of a school. Hoyle (1986) in Kyoshaba (2006) argued that schools are established with the aim of imparting knowledge and skills to those who go through them and behind all this is the idea of enhancing good academic performance. The educational administrators of schools A and B were concerned about those who did not perform well in A' Level Agriculture because if this poor performance goes unchecked, the schools may lose their reputations and hence enrolment would be negatively affected. Much as the situation described here causes concern, it is not yet known why some students fail to attain the standards expected of them. Several researches have been carried out locally and abroad but no research has been done in the Midlands province's high schools to ascertain factors affecting academic performance of A' Level Agriculture students.

Having worked at full throttle to translate the philosophy of compulsory education into reality, the focus of the Zimbabwean government now is on the improvement of the quality and relevance of education. Failure of students at school means the government, which would have invested in their education, makes a loss. The students would not be able to proceed to colleges and universities and students would have wasted time pursuing a subject they would not benefit from. Parents get worried about the fees they will have paid for their children. This study therefore sought to find out factors that could be contributing to low performance in the ' $\mathrm{A}$ ' Level Agriculture syllabus (9159) in the two selected high schools and come up with insights and suggestions on how the performance can be improved.

\section{Research objectives}

The study sought to:

- Establish challenges schools in the Midlands Province, Zimbabwe, faced in the teaching/learning of 'A' level Agriculture Syllabus (9159)?

- Determine how the challenges contribute to poor performance by schools in 'A' level Agriculture?

\section{Significance of the study}

The findings of this study could provide insights on how to achieve quality education in 'A' Level Agriculture in comparable schools in Zimbabwe. The study would also provide insights into the problems whose solution might help inform specific actions to be taken to efficiently and effectively address the poor performance in A' Level Agriculture. This study would not only assist the Department of Education and School Management Teams of high schools to improve their level of performance in A level Agriculture, but also provide strategies to guide the schools that offer A' Level Agriculture on how to improve the performance of learners to a level that would allow them to pursue Agriculture programmes in higher and tertiary learning institutions. The study would also be helpful to the Ministry of Primary and Secondary Education, Zimbabwe, for determining which schools should offer 'A' Level Agriculture and to monitor their performance. School administrators would also be assisted in selecting students who qualify to take up the subject.

\section{Literature review \\ 4.1 Challenges schools face and their contribution to poor performance}

Awe (2002) in Medinat (2007) revealed through her study that parents' attitude towards Agricultural Science has an impact on students' performance in the subject. She discovered that students whose parents' attitude towards Agricultural Science is encouraging performed better in the subject compared to students whose parents have a non-challant attitude towards the subject. In general the performance of students in this subject depends on parental interest more so in Zimbabwe where during the colonial rule the subject was meant for the less academically gifted students. In the same vein, Oladele et al (1993) in Medinat (2007) discovered that lack of qualified teachers, lack of well-equipped libraries, parental or guardian influence, attitude of students, instructional materials and time allocation were other important factors affecting students' performance in Agricultural Science in secondary schools. In Zimbabwe, most high schools especially in rural areas do not even have a library such that the only textbook available would be for the teacher.

In another study on performance, Bonga (2010) indicated that family (e.g., parental education) and personal (e.g., nutritional history) factors, demographic factors (e.g., walking distance to school), in combination with social characteristics (e.g., age, sex and English proficiency), contribute to the academic progress of school children. He also hypothesized that the language spoken at home would affect student learning. In most Zimbabwean families vernacular is used yet the language of instruction at school is English. Schools thus use the 'wrong' language to talk about their culture resulting in poor grasping of concepts by students. Teaching/learning of Agriculture is no exception. 
The socio-economic background of students affects their performance in school. Poor parental background contributes to poor performance by their children. The learner's background relating to availability of educational resources at home; like books, electronic resources such as television, computer, study desk and table for their own use and general academic support at home are crucial. Learners who have access to such resources have a sound head start compared to those from poor families since they will be more informed about the latest developments around them thereby assisting them to improve their performance at school (Ramala, 2009). Thus, non-exposure to educational resources on learners from poor families affects their performance compared to their counterparts who have access to such resources. There is a lot of educational information that can be accessed through the TV and computers that are connected to the Internet to assist learners source information for school assignments and projects.

In a study on performance, Kiadese (2011) found out that problems such as poor school infrastructure, lack of qualified teachers, poorly equipped workshops and laboratories as well as parents' attitudes affect the teaching of prevocational subjects like Agriculture. These findings are consistent with those of Uwaifo and Uwaifo (2009) who established that in Nigeria there was still a strong tendency towards white-collar jobs as a result of the low status associated with most kinds of technical and vocational education. Because of this cold attitude towards technical and vocational education, some decision makers do not think the subject is sufficiently important to deserve funding. This negative attitude has an indirect but strong influence on student performance in technical subjects of which Agriculture is one.

Accordingly, findings of a study by Mandima (2012) have also revealed that the greater percentage of Food and Nutrition teachers in Zimbabwe were underqualified. The findings indicate that there are inadequate Food and Nutrition teachers in the schools. On the other hand the only available teachers are not adequately trained; hence they lack the innovativeness and resourcefulness entailed in the teaching and learning of Food and Nutrition. Similar scenarios could also haunt the teaching of 'A' Level Agriculture in Zimbabwe.

The other challenge identified was that of poor societal perception. The majority of the parents and most of the students who participated in the Mandima (2012) study (above) had a negative attitude towards practical (vocational) subjects and looked down upon technical and vocational education teachers regarding them as failures in life (Mandima, 2012). This attitude has continued to stifle both the implementation progress and performance in these subjects.

The location, ownership, academic and financial status of schools do count in making a school what it is and in turn influences the academic performance of its students because they set the parameters of a students' learning experience. According to Saiduddin (2003) it is a convenient scapegoat to pass the blame and responsibility for the low academic performance to factors such as socio-economic status, family, culture and the learner being less intelligent than the others. The research he conducted at high schools in South Dakota showed that all learners are educable, and that the way in which the school is managed is the most critical factor in determining the quality of education for its learners. The study was undertaken at a high school and the bone of contention was how students can pass a subject without the necessary learning materials and equipment. This may apply to ' $A$ ' Level Agriculture in Zimbabwe since it is a practical subject which requires facilities like laboratories, equipment and other materials to carry out practical operations. If a school offering the subject cannot provide these requirements, there is a possibility that students will not perform well. Schools that offer students a positive learning environment, including the use of technology in the classroom and a quality library, give students an edge in mastering Mathematics, English and Science subjects. Up-to-date textbooks and other materials to use during lessons and other teacher presentations are also important (Ketchum, 2013).

Most schools in the Midlands Province of Zimbabwe are rural based and poorly resourced. In another study in Zimbabwe, Makopa (2011) discovered that schools with more resources had higher achievement scores than those with fewer resources. Therefore where there were limited or no resources the pupils had low academic achievements showing that there is a strong correlation between the level of provisions and the pupil's achievements. So resource availability is a contributory factor to performance in schools.

Motivation is also a requirement for effective learning. A study in England noted many factors that influence both the rate and enjoyment of learning (Mullins, 2005). Once an individual has experienced something, and has stored that experience, the individual is able to refer to and use it at a later stage. As such, learning and memory are inextricably linked. The reward and punishment levelled at learners in the past will affect their motivation and attitude towards learning in the present. The expectations of others and the climate which surround learners will determine their readiness to learn, which in turn will affect their academic performance (Mullins, 2005). Another study suggests that maintenance of high motivation influences psychological and social functioning and facilitates academic performance as well as positive school perceptions (Gilman \&Anderman, 2006). The learning environment therefore has an impact on performance by students.

Learner attitude towards learning also affect their performance. Attitudes are learned throughout life and are embodied within our socialisation process. The negative attitude towards learning could result in learners performing poorly preventing them from obtaining required results for university entrance. In a study by 
Mbugua etal (2012), students' personal factors contributing to poor performance in Mathematics were found to be gender, economic factors and attitude towards Mathematics. Mwamwenda (1995) argues that the achievement of students in a subject is determined by their attitudes rather than inability to study. Haimowitz (1998) in Mbugwa et al (2012) indicated that the cause of most failures in schools might not be due to insufficient or inadequate instruction but by active resistance by the learners. This argument suggests that favourable attitudes towards a subject should be developed for better achievement in the subject. In her study, Biriwasha (2012) noted that the dwindling popularity of Agriculture among the younger generation reflects a general trend towards de-agrarianisation in the continent linked to environmental degradation and reduced availability of land, economic pressures which have undermined peasant agriculture, and a realignment of rural populations' changing aspirations. This leads to the students not taking the subject seriously thereby affecting their performance.

The findings by Hedjazi and Omidi (2008) indicated a positive significant relationship between a student's academic success in Agriculture and his/her family members' attitude towards education and learning. In this study there was also a significant difference observed between a male and a female student's success in which female students were more successful. On the other hand, Savelyeva (2005) proposed that male students outperform their female counterparts in Science; Technology, Engineering and Mathematics while female students most likely excel in Humanities, Social Science and Writing. This clearly points out that the problem is on the attitude of the learner, and not necessarily gender.

A student's negative behaviour within an educational environment may just be the result of how that environment is presented. Classroom motivation may be affected by how the teacher provides encouragement, opportunities, structure and a strong student-teacher relationship. The research conducted in Spain (Marchesi\& Martin, 2002) found that the relationship between the learner and educator are some of the factors that determine academic performance.

Characteristics of the educator are considered as key elements for the learner's personal and academic development. Hence, it is crucial that educators should be role models worth emulating by the learners. Research by Castejon\&Perez in Diaz, (2006) revealed that the educator's expectations significantly influence the learner's results. In other words the greater the learner's intelligence, the better the academic results and the better reciprocal appreciation between the educator and the learner. In line with that, Harmon (2004) found out that test performance is influenced greatly by teacher attitudes and expectations of students. Teacher pupil relationships could have some influence on teaching and learning of 'A' Level Agriculture hence student performance. Teachers are significant role players in shaping students' attitude and achievement in their study (Erawan, 2010). Therefore, Agricultural Science teachers are the main source and facilitators of the knowledge transfer in the subject schools. In this respect, the level of knowledge being acquired by students depends, in part, on the level of knowledge and attitude of their teachers (Rezaei et al., 2008; Lashgarara, 2011). Therefore, the teacher's qualification and attitude towards his/her work have a significant impact on student performance.

\section{Methods}

This case study employed the descriptive survey research design. A census was used to select all the participants; 25'A' Level Agriculture students and their three teachers. While sixteen (16) of the students were males, nine were females. The teachers were composed of two males and one female. This selecting technique entailed purposive sampling since the respondents were regarded rich in information about performance in ' $A$ ' Level Agriculture. The research used questionnaires for Agriculture students and interviews for the teachers to collect data. The research developed some open- ended questions so that the respondents were not restricted in their responses (Jagg, 2013). The research used the general interview guide approach which according to Shrivastava (2003) is intended to ensure that the same general areas of information are collected from each interviewee; this provided more focus than the conversational approach, but still allowed a degree of freedom and adaptability in getting the information from the interviewee. This assisted the research to covertly unravel the teachers' opinions, views, attitudes and feelings regarding their schools poor performance in ' $A$ ' level Agriculture. A pilot study was carried out on 'A' Level Agriculture students and teachers who were not used in the actual study. The comments from the pilot study were used to amend the instruments in order to safely use them on the actual participants. Permission to carry out the research was sought from and granted by the Ministry of Primary and Secondary Education, Zimbabwe. The data collection instruments were administered by the researchers in person with the lead researcher conducting the interviews and the assistant researchers manning the administration of the questionnaires. Respondents were guaranteed anonymity and confidentiality of the information they gave.

\section{Results and Discussion}




\subsection{Demographic Data of Respondents}

Distribution of respondents by gender showed that the subject Agriculture, a Science subject, tended to be dominated by males than female students. Savelyeva (2005) observes that male students outperform their female counterparts in Science; Technology, Engineering and Mathematics while female students most likely excelled in Humanities and Social Sciences. However, Hedjazi and Omidi (2008) in their study on academic success in Agriculture found out that there was a significant difference observed between a male and a female student's success in which female students were more successful.

Fig 1 below shows that all the student respondents (25) did and passed Agriculture at ' $\mathrm{O}$ ' Level. Of these 23 passed Integrated Science followed by 22 who passed Geography. The least frequency was 11 for Physical Science.

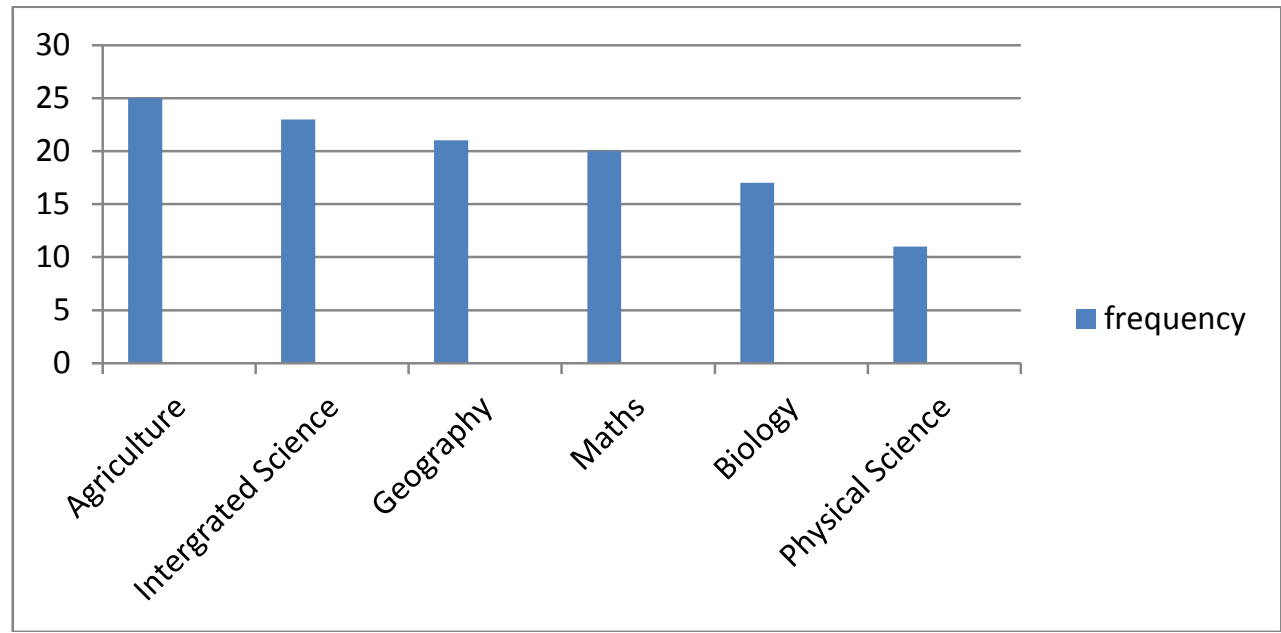

Fig 1: Distribution of Respondents by Science Subjects Passed At 'O' Level

Integrated Science covers the basic scientific concepts and this indicates that the majority of the participants had relevant basic science hence Agriculture- related knowledge. In his study, Olowa (2009) recommended that Science, Mathematics and overall performance of a student should be considered when counselling them to take Agricultural Science at senior secondary school level. The Zimbabwe 'A' Level Agriculture syllabus (9159) has scientific concepts that require a strong background in Biology, Chemistry and Mathematics. The syllabus places much emphasis on the understanding and application of scientific concepts and principles of Agriculture and this focus has been adopted in recognition of the need for students to develop skills that will be relevant in the world of work (ZIMSEC, 2008). The interviewed teachers underscored that most of the students that were doing ' $A$ ' Level Agriculture had problems with Mathematical calculations and mastering those concepts that apply to Chemistry. One of the students even indicated that he had not attempted Mathematics at ' $\mathrm{O}$ ' Level. This research also noted from the questionnaires that most of the participants had Grade Cs in Mathematics at 'O' Level.

'A' level Agriculture students combine the subject with two other subjects. Table 1 below shows students other subjects.

\section{Table 1: Distribution of Students' Subject Combination with Agriculture} $(\mathbf{N}=\mathbf{2 5})$

\begin{tabular}{|l|c|}
\hline Subject & Frequency \\
\hline Biology & 17 \\
\hline Geography & 13 \\
\hline Mathematics & 12 \\
\hline Economics & 4 \\
\hline Business Science & 3 \\
\hline Chemistry & 2 \\
\hline Technical Graphics & 2 \\
\hline Physical Science & 1 \\
\hline
\end{tabular}

From Table 1 above, most students combined Agriculture with Biology ( $\mathrm{N}=17)$, followed by Geography $(\mathrm{N}=13)$ and Mathematics $(\mathrm{N}=12)$. Chemistry which is a principal requirement was only studied by 2 students. While Economics is not closely related to Agriculture, there is a component of Agricultural Economics in the subject. Only one of the participants was combining Agriculture with Physical Science and a third subject yet the syllabus component of Agricultural Engineering requires knowledge of the Physics component in Physical Science. Agriculture teachers interviewed also confirmed the same problem in Agricultural Engineering faced 
by the learners. They indicated that some of the students were combining Agriculture with unrelated subjects. This would not provide a good background and link to the Agriculture concepts.

Respondents indicated their level of agreement with the fact that they faced challenges in the 'A' Level Agriculture syllabus (9159) as shown in Fig 2 below.

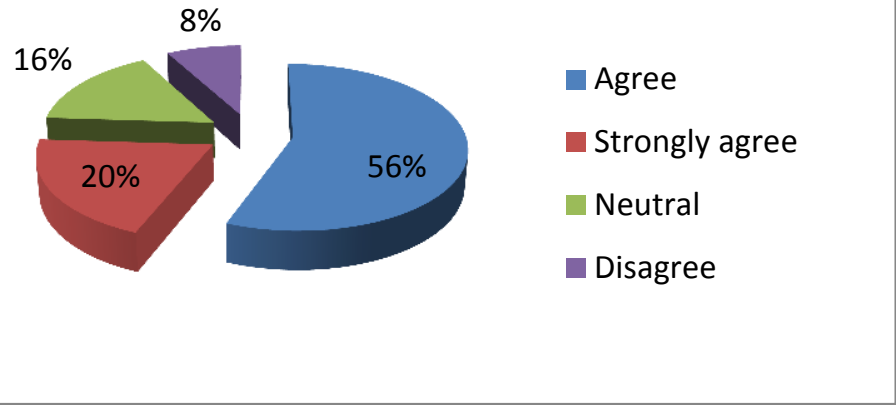

Fig 2: Students Responses on Their Challenges in 'A' Level Agriculture ( $N=25)$

From Figure 2 above the majority $(56 \% ; n=14)$ of the participants strongly agreed followed by $20 \%(\mathrm{n}=5)$ who agreed that they were facing challenges in 'A' Level Agriculture. The least, $8 \%(\mathrm{n}=2)$, disagreed that they were facing challenges. It can be noted that $76 \%(56 \%+20 \%)$ which translates to $(n=19)$ of the participants were actually facing challenges in 'A' Level Agriculture. Those participants who indicated that they were not facing challenges went on to explain that they were getting assistance from relatives in terms of textbooks and other related reading materials. In the interviews carried out, teachers indicated that some of the textbooks and reading materials were too comprehensive for ' $A$ ' Level students.

Respondents also indicated their views on factors contributing to poor performance in 'A' Level Agriculture syllabus (9159). Their responses are shown in Table 2 below.

Table 2: Respondents Views on Factors Contributing To Poor Performance in ' $\mathrm{A}$ ' Level Agriculture $(\mathbf{N}=\mathbf{2 5})$

\begin{tabular}{|l|l|}
\hline Respondents' Views & Frequency \\
\hline Lack of equipment & 23 \\
\hline No Textbook for the 'A' Level syllabus & 22 \\
\hline Lack of qualified 'A' Level Agriculture teachers & 13 \\
\hline Lack of funding for field trips and seminars & 12 \\
\hline Long complex syllabus & 11 \\
\hline Parent/guardian negative attitude & 11 \\
\hline Lack of Information Communication Technologies (ICTs) & 10 \\
\hline Difficult project work & 8 \\
\hline Lack of student interest towards subject & 5 \\
\hline Poor subject combination & 1 \\
\hline
\end{tabular}

As shown in Table 2 above, of the 25 student participants, the majority $(n=23)$ indicated lack of equipment as a factor contributing to poor performance in 'A' Level Agriculture followed by 22 who indicated that they had not come across any textbook which addresses the Zimbabwe 'A' Level Agriculture syllabus (9159).The least frequency of poor subject combination was raised by one student respondent.

The results are in line with the findings by Saiduddin (2003) who argues that students cannot pass a subject without the necessary materials and equipment in learning the subject. ' $A$ ' Level Agriculture in Zimbabwe is a practical subject which requires facilities like laboratories, equipment and other materials to carry out practical operations (ZIMSEC, 2008). The interviewed teachers confirmed that there was no 'A' Level Agriculture textbook for the syllabus. They further indicated that they resorted to the use of university modules and textbooks whose information may not be suitable for the scope of the syllabus. According to Ketchum (2013) up-to-date textbooks and other materials to use during lessons and other teacher presentations are important. Such findings are consistent with those by Kiadese (2011) who found out that problems such as poor school infrastructure, lack of qualified teachers, poorly equipped workshops and laboratories affect the teaching of prevocational subjects. In another study in Zimbabwe, Makopa (2011) discovered that schools with more resources had higher achievement scores than those with fewer resources. Most schools in Zimbabwe have poorhuman and material resources.

This research also discovered that some of the teachers were trained to teach but do not qualify to teach 'A' Level Agriculture. While they did Agriculture at college, at university they went through programmes that were not related to Agriculture. Hence they were facing challenges in teaching the subject. The acquisition of 
skilled and dedicated specialised teachers is believed to be the key to an efficient application of curriculum content (Narman, 1995). This is consonant with (Rezaei et al., 2008; Lashgarara, 2011) who are of the opinion that the level of knowledge being acquired by students depends, in part, on the level of knowledge and attitude of their teachers. Therefore, the teacher's qualification and attitude towards his/her work have a significant impact on student performance. In support of some of the students' view that lack of interest towards the subject contributed to poor performance, the interviewed teachers were also worried about the negative attitude of some students towards the subject. They made indications that students did not take the subject as seriously as they did other subjects. In her study, Biriwasha (2012) noted that the dwindling popularity of agriculture among the younger generation reflects a general trend towards de-agrarianisation in the continent linked to environmental degradation and reduced availability of land, economic pressures which have undermined peasant agriculture, and a realignment of rural populations' changing aspirations. In the same vein, Mwamwenda (1995) argues that the achievement of students in a subject is determined by their attitudes rather than inability to study.

The negative attitude of the students could be related to the negative attitude by parents/guardians highlighted by some of the students in their responses. Awe (2002) in Medinat (2007) revealed through her study that parents' attitude towards Agricultural Science has impact on students' performance in the subject. She discovered that students whose parents' attitude towards Agricultural Science is encouraging performed better in the subject compared to students whose parents have a non-challant attitude towards the subject. UNICEF (2000) also highlighted that quality education included, among others, children who are healthy and supported in learning by their families and communities. In his study, Mandima (2012) found out that the majority of the parents and most of the students who participated in the study had a negative attitude towards practical (vocational) subjects and looked down on vocational and technical education teachers and regarded those who practiced it as failures in life. This poor societal perception seems to have an impact on the performance of ' $\mathrm{A}$ ' Level Agriculture learners at the two selected schools.

Table 3: Respondents' Views on Strategies to Improve Performance in 'A' Level Agriculture $(\mathbf{N}=\mathbf{2 5})$

\begin{tabular}{|l|c|}
\hline Respondents' view & Frequency \\
\hline Schools to provide equipment and materials & 17 \\
\hline Printing of an 'A' Level Agriculture textbook & 16 \\
\hline Provision of qualified teachers & 12 \\
\hline Provision of Information Communication Technologies (ICTs) & 10 \\
\hline Funding for field trips and seminars & 8 \\
\hline Requirement of a functional laboratory & 8 \\
\hline Government and NGO support on resources & 7 \\
\hline Syllabus review & 7 \\
\hline Provision of project and experimental guides & 4 \\
\hline Subject to be offered in schools that can afford & 4 \\
\hline Students should be motivated & 3 \\
\hline Parents should be conscientised on the importance of Agriculture & \\
\hline
\end{tabular}

Table 3 above shows that 17 of the 25 student participants suggested that schools should provide equipment and materials. This was followed by 16 who suggested that a relevant 'A' Level textbook should be produced. The least, one respondent, suggested that parents should be conscientised on the importance of Agriculture.

The above information shows that most of the suggested strategies are related to the factors highlighted in Table 2 above since they relate to the problems that may be contributing to poor performance in ' $\mathrm{A}$ ' Level Agriculture. The interviewed teachers also highlighted that there was need to have an ' $A$ ' Level Agriculture textbook printed, need for qualified teachers and provision of some Information Communication Technologies (ICTs) like computers and internet access. All these suggestions made by teachers were highlighted in the questionnaires by students'. In their studies Mafa and Makuba (2013), Mufanechiya et al (2012) suggested that schools should be well resourced in order for performance of students to improve. Students' suggestion about the need for proper Government funding was supported by Akanle (2007), Mbugua et al (2012), Bonga (2010) and Makopa (2011) who recommended in their studies that governments and NGOs should work together in ensuring that schools are properly funded. From their findings, Riddel and Nyagura (1995) highlighted the need for qualified teachers for academic performance to improve in Zimbabwe. The same was also suggested by student respondents in this research. The view by one of the respondents that parents should be conscientised on the importance of Agriculture is in line with recommendations by Mafa and Makuba (2013) and Mufanechiya et al (2012) who highlighted that parents need to be conscientised on the importance of their children's education. According to Killian and Baker (2006) there is need for increased support from the school administration in order for student performance to improve as has been highlighted by some of the students. 


\section{Conclusions and Recommendations}

From the findings, it can be concluded that:

- Shortage of equipment and materials to use for practical lessons and projects is affecting performance in 'A' Level Agriculture at schools A and B in Midlands.

- Shortage of teachers qualified to teach 'A' Level Agriculture is contributing to poor performance in the subject at schools A and B in Midlands.

- Lack of ICTs contributes to poor performance in 'A' Level Agriculture at schools A and B.

- Provision of a textbook designed for 'A' Level Agriculture can guide the teachers and students in the teaching and learning and hence improve performance.

- Availability of teachers qualified to teach 'A' Level Agriculture can help to improve performance at schools A and B in Midlands.

- Government and NGO support on resource allocation can help to improve performance in 'A' Level Agriculture at schools A and B.

The study recommends that:

- Schools should be strictly assessed on their ability to provide the required infrastructural base and equipment before they are recommended to offer the Zimbabwe 'A' Level Agriculture syllabus (9159).

- 'A' Level Agriculture textbooks should be printed for use in schools.

- Agriculture teachers should be encouraged to further their studies to be able to teach the subject up to 'A' Level.

- Qualified Agriculture teachers should be well paid and incentivized so that they do not to go abroad for greener pastures

- Workshops should be held to make Agriculture teachers keep in touch with the requirements of the ' $\mathrm{A}$ ' Level Agriculture syllabus (9159).

- ZIMSEC should provide feedback after marking ' $\mathrm{A}$ ' Level Agriculture to assist teachers in coaching the students for examinations.

- Government with the help of NGOs should support schools through funding school Agriculture programmes.

- School administrators should prioritise the funding and expose learners to the syllabus requirements through seminars and field trips.

- Use of ICTs in teaching and learning of 'A' Level Agriculture should be given a priority to improve student performance.

- Parents and guardians should be conscientised on the importance of Agriculture and the avenues that it can open in the educational lives of their children.

- Replica studies should be conducted in other high schools offering 'A' Level Agriculture to verify findings from this study.

\section{References}

[1]. Akanle, O.B (2007) Socio-economic Factors Influencing Student Academic Performance in Nigeria [Online] http://www.freeonlinelibrary.com

[2]. Ariko (2009), Factors Influencing Low Academic Performance of pupils in Rural Schools in Uganda.[Online] http://www.scribd.com

[3]. Beeman, D (2013), Types of instruments in research. [Online] http://www.answers.com

[4]. Biriwasha, L (2012), Agriculture in the School Curriculum in Zimbabwe, FAC Early Careel Fellow, Zimbabwe.

[5]. Bonga (2010), Determinants of Poor Academic Performance[Online]http://www.articlebase.com

[6]. Crow, M \& Sheppard, L (2011), Qualitative Methods, [online] http://www.ijahsp.nova.edu. Cunningham, B (1993) Child Development, Harper Collins Publishers, New York.

[7]. De Vos A.S (2001), Research at grassroots ( $3^{\text {rd }}$ Edition), Van Sheik Publishers, Pretoria.

[8]. Diaz, A.L (2005), Personal, family and academic factors affecting low achievement in Secondary School.[Online] http://wwww.investigacion.psychopedagogica.org

[9]. Elmore, R (2009), The only three ways to improve performance in schools [o] http://www.uknow.gse.harvard.edu

[10]. Gillman, R \& Anderman, E.M (2006), The Relationship Between Intrapersonal and Interpersonal Motivation and Academic Functioning Among Older Adolescents, Journal of School of Psychology (44)3, 9-10).

[11]. Harman, D (2004), Improving Test Performance among Culturally Diverse Gifted Students [online] http://www.davidsongifted.org

[12]. Hedjazi, Y\& Omidi, M (2008), Factors Affecting the Academic Success of Agricultural Students at University of Tehran, Journal of Agricultural Science (), Iran.

[13]. Hodgkinson, S (1999), The Demographics of American Indians, Institute of Educational Leadership, Washington.

[14]. Holstein, B \& Gubrium J, F (1995), The active interview, Sage Publications, Thousand Oaks.

[15]. Jagg, X (2013) Interview Method vs. Questionnaire [online] http://www.ehow.com

[16]. Kellaghan, T \& Greany, V (2003), Monitoring Performance Assessment and Examinations in Africa [online] http://www.toolkit.ineesite.org 
[17]. Ketchum, D (2008), Factors Affecting Effective Teaching [online] http://www.ehow.com

[18]. Kiadese, A.L (2011), An assessment of the teaching effectiveness of prevocational subject teachers in Oguni State Nigeria, Journal of Vocational and Technical Education. [Online] http://www.journals.org

[19]. Killian, J.N and Baker, V.D (2006) The Effect of Personal Situational Factors in the Attrition and Retention Texas Educators, Journal of Education 16(45).

[20]. Kyoshaba, M (2009), Factors Affecting Academic Performance of Undergraduate Students at Uganda Christian University. (Online) http://www.docs.mak.ac.ug

[21]. Mafa, O and Makuba, E (2013), The Involvement of Parents in the Education of their Children in Zimbabwe's Rural Schools: The Case of Matabeleland North Province, Journal of Research Methods in Education [online] http://www.ijsr journals.org

[22]. Mandima, S (2012), Challenges of Implementing the Food and Nutrition Curriculum in Secondary Schools in Chivi district, Zimbabwe. (Online) http://www.palgrave.com

[23]. Marchesi, A. and Martin, E. (Eds.), (2002), Evaluation in Secondary Education: Snapshot from a controversial era. Institution IDEA, Madrid.

[24]. Mbugua, Z.K etal(2012) Factors Contributing to Poor Performance in Mathematics in Kenya Certificate of Secondary Education, Chuka University College Journal 4(6), Kenya.

[25]. Medinant, M.O, (2007), Factors influencing achievement in School Certificate Exam in Nigeria, (online) http://www.met.ubc.ca

[26]. Mufanechiya, A et al (2012), Challenges faced by Zimbabwean Schools that Perform Poorly. [Online] http://www.resjournals.com

[27]. Munikwa, S (2011), Analysis of the current Zimbabwe's Secondary School Two Pathway Education Curriculum, Journal of Innovative Research in Education 1(1): 23

[28]. Mwamwenda, T.S (1995), Educational Psychology: An African Perspective, Heinemann Butterworth Publishers Ltd, London.

[29]. Narman, A (1995), Education, training and agricultural development in Zimbabwe, International Institute for Education and Planning [online] http://www.unesdoc.unesco.org

[30]. Neuman W. L (2006), Social Research Methods: Qualitative and Quantitative Approaches, Pearson Education Inc, Cape Town.

[31]. O'conour, B. (1999), How to Help Students Improve Academic Achievement and School Success Behaviour (online) http://www.ehow.com

[32]. Olaiwola etal (2011), On Statistical Analysis of Impact of Socio Economic Factors on Students' Academic PerformanceIJTRAS 8(3) (online) http://www.arpapress.com

[33]. Olowa, O.W (2009), Identifying Predictors of Secondary School Performance in Agricultural Science in Nigeria Federal College of Education (Tech) EJREP 7(19), 16-18

[34]. Riddell, A.R \& Nyagura, L (1991) What causes differences in Achievement in Zimbabwe Secondary Schools (online) http://www.wds.worldbank.org

[35]. Rumberger, R (2010), Improving High School Performance, (online) http://www.tltjc.blogspot.com

[36]. Saiddudin, (2003), Factors Affecting Achievement at Junior High School, Ohio State University, Spain.

[37]. Savelyeva, T (2005) Understanding Gender Variations in Performance of Agricultural Education Students through a Qualitative Approach

[38]. Sobrepona, Y (2013), The

[39]. Stachowiak, J (2008) Pilot Study (online) http://www.ms.about.com

[40]. UNICEF (2000), Defining Quality in Education. (Online)http://www.unicef.org

[41]. Uwaifo, V.O and Uwaifo, LU (2009), Training Technology and Vocational Educational Teachers, NGO Journal 4(4) (online) http://www.academic.com

[42]. ZIMSEC (2008), A’ Level Syllabus: Agriculture (9159) (online) http://www.zimsec.co.zw 